\title{
Development of Maritime Law in China Within the Last Five Years: Maritime Legislation, Cases and Jurisdiction
}

\author{
Ma Deyi", Zhou Mingyuan \\ International Law School, East China University of Political Science and Law (ECUPL), Shanghai, China \\ Email address: \\ madeyi9@aliyun.com (Ma Deyi), cynthia_09115@.163com (Zhou Mingyuan) \\ ${ }^{*}$ Corresponding author
}

To cite this article:

Ma Deyi, Zhou Mingyuan. Development of Maritime Law in China Within the Last Five Years: Maritime Legislation, Cases and Jurisdiction. International Journal of Law and Society. Vol. 7, No. 3, 2019, pp. 89-99. doi: 10.11648/j.hss.20190703.12

Received: January 29, 2019; Accepted: June 5, 2019; Published: June 26, 2019

\begin{abstract}
This paper examines the development of maritime law in China within the last five years, from the perspective of China's maritime legislations, cases and jurisdiction of the court, in light of the latest national strategies, such as building China into a maritime power, implementing the "Belt and Road" initiative and building China into an international shipping hub. Chinese maritime law is anticipating a reform. China has implemented various maritime-related laws and regulations in recent years, including the 2014 Waterway Law. Besides, the 12th National People's Congress Standing Committee has formally ratified the International Labour Organization's 2006 Maritime Labor Convention at its 16th meeting on August 29th, 2015. The Supreme People's Court has released ten maritime model cases in the conference celebrating the 30th anniversary of establishing maritime court in China. These model cases offer valuable guidance to maritime trials in the future. To improve the maritime adjudication and to turn China into a judicial hub for international maritime matters, China has undertaken reform to confer maritime court with jurisdiction to hold criminal hearings. Ningbo Maritime Court held a public court hearing over the case of "Catalina". It was the first criminal hearing in the maritime court of China. New elements of reform on criminal jurisdiction were also demonstrated in the trial of the case. Another important measure taken to perfect the admiralty jurisdiction in China is the regular publication of White Papers on maritime issues. These White Papers have summarized and highlighted some of the important maritime trials by the Maritime Courts in recent years. Meanwhile, the Supreme People's Court has issued the Notice of the Supreme People's Court on Issuing the Provisions on Case Guidance, which has made specific provisions on the guiding cases. Amongst the guiding cases released, some of them are relate to maritime matter.
\end{abstract}

Keywords: Chinese Maritime Law, Legislations, Jurisdiction

\section{Introduction}

On the one hand, with the rapid development of China in the past decades, the volume of foreign trade has increased drastically and the country's economy has reached a mature state. The continuous progress of social modernization and market privatization has reshaped the country. However, the legal system of the country is not mature enough. One of the major issues the Chinese legal scholars concerned about is the lack of a unified Civil Code, which has caused great trouble to the application and understanding of the law. [1] Therefore, a systematic reform of the Chinese civil law becomes necessary. In 1998, the Standing Committee of the National People's Congress proposed to conduct a step-by- step codification of the Chinese Civil Code. [2] Since then, there has been ongoing work on redrafting the Chinese civil law. [3]

On the other hand, the Chinese maritime law also urges for reform. China has its unique system of maritime law. Instead of rectifying the international Conventions, China has learnt from the international maritime Conventions and set its own rules. Therefore, it is the country's legislator who determines the fairness and internationalized standard of maritime law. Maritime Law of the People's Republic of China, also referred to as the Chinese Maritime Code (CMC), was promulgated more than 20 years ago and is now obviously 
outdated.[4] The constant development of shipping business, maritime transportation and judicial practices in China calls for a change on Chinese maritime law and regulations. Many issues, such as seamen's protection and liabilities for oil pollution, are not included in the CMC. So the CMC is unable to catch up with the development of the shipping economy and is likely to lag behind the pace of international maritime Conventions.

Besides, as Robert Grime speculates, maritime law is not only a composite of special laws based upon the practice and custom of merchants and seafarers, but it is necessary and usual to have special courts to carry them out. [5] This has also been the practice in China. Ten maritime courts have been established since 1984, when trading and transportation by sea in China soared. Decades have passed and it is time to review the practice of maritime law in China and sweep away the flaws in the maritime code. Moreover, the reform of Chinese maritime law will be highly beneficial to China's national strategies - building China into a maritime power, implementing the "Belt and Road" initiative and building China into an international shipping hub.

Since codification of Chinese Civil Code and reform of the Chinese Maritime Code are both necessary at the moment, amendment of one would affect the other. Moreover, the international legal development also has an impact on the two intended reforms, especially the CMC. CMC should be modernized to be geared to international standards. However, the revision and perfection of the $\mathrm{CMC}$ is a tough mission.

Meanwhile, ratification of the international maritime Conventions has always been an option for China to take. Whether China should ratify the Rotterdam Rules has been a hot potato since 2008 . To date, there is a lack of international consensus on the adoption of Rotterdam Rules and different countries have reacted differently. Only a few countries have ratified the Rules. [6]

Leaving aside the complex issues of reforming $\mathrm{CMC}$, the Chinese maritime courts have tried many cases. The highest Court of China - Supreme People's Court has released ten maritime model cases. Although China is a civil law practiced country to which the common law principle of stare decisis does not apply, these cases still worth discussing as they help to demonstrate the theory and practice of maritime law in China. Moreover, to adapt to the development of the shipping industry, China has also enacted several maritime legislations.

\section{Revision of CMC and Recent Maritime Legislations}

\subsection{The Need for Revision of CMC and Impact of Codification of the Chinese Civil Law on the Revision of CMC}

In terms of Chinese Civil Law codification, maritime law cannot be omitted since it has a close link with various branches of the Chinese Civil Law. Maritime law is one of the Supplementary Special Civil Laws (SSCL) to the Chinese law. From the jurisprudential perspective, it is subsidiary to the Chinese Civil Law. Even if CMC's provisions are quite comprehensive and the Code has been relied on as the only governing and relevant law in many cases, there are occasions where CMC alone is inadequate. For instance, $\mathrm{CMC}$ has stipulated that the limitation period for bringing any claims against carrier regarding carriage of goods by sea is one year. [7] However, it is unclear whether the same limitation rule applies to carrier's claims against shipper. [8] Since a plain reading of the text of the specific law (CMC) cannot provide the answer, the interpretation is open to Judges for decision. The court could either interpret Article 257 widely as that the limitation rule's application can be extended to carrier's claims against shipper, or as that only the general law - Chinese civil law's limitation rule applies, because the special law (CMC) does not have any provisions that prevail over the application of the general law.

Nevertheless, either way is unsatisfactory. China is a civil law country and there is no precedent. Judicial decisions do not have binding effect and cannot be the basis for the ruling of future cases. The Courts have no obligation to follow previous decisions. Thus, judicial decisions are incapable of setting precedent and be the once-and-for-all solution. Although the Supreme People's Court could issue legally binding "judicial interpretation" to fill the gap in CMC, [9] it is doubtful whether the Court has the necessary wisdom and capacity to give far-reaching interpretation of the Code which amounts to legislation.

Further, it is argued that judicial interpretation should be issued only when it is strictly necessary for it lacks NPC's thorough scrutiny. It would undermine the National People's Congress's legislative power and the NPC-made law - CMC and Chinese civil law's status. It would cause contradictions and inconsistencies to the Chinese civil law system. Thus, the best solution for all the imperfections of CMC is to reform.

As discussed in one of the author's paper, maritime law is one of the most sophisticated SSCLs of China. [10] There are at least four major characteristics contributing to its complexity. Firstly, modern maritime law is a fusion of domestic civil law, international Conventions and merchant practice. [10] Rewriting China's maritime code is not just a simple domestic issue, but has to take into account of many different factors, including the development of shipping law in other major shipping countries. Secondly, maritime law does not originate from a particular domestic legal system. [10] Rather, it began as "lexmaritima", a set of rules developed by persons for determining disputes over trade, navigation and other maritime matters among themselves. As such, the practice of maritime law does not fit squarely into the domestic civil law. Maritime law has its own value and characteristics, such as the "in rem" claims. Thirdly, maritime law involves both public and private law. [10] It is not just a set of rules that only governs or affects merchants, it also involves the government's exercise of sovereignty. Fourthly, maritime law is complicated due to its close link with contract law. [11] All of the above mentioned factors cause difficulty to the reform of Chinese maritime law. 
The codification of Chinese Civil Law will also affect the reform of $\mathrm{CMC}$, depending on whether the codification takes place before or after the revision of Chinese maritime law. If the maritime law is revised after the codification of Chinese Civil law, the new CMC will have to adapt to both the domestic and international environment and go well with Chinese Civil Law.

However, if the Chinese maritime law is revised before the codification of the Chinese civil law, the revision will have to be based on the predicted outcome of the civil law codification. There will be new disharmony between the maritime law and the general civil law, leading to the need for a second modification of the maritime law. [12]

\subsection{The Modernization of CMC - The Content}

In context, Chinese maritime law is probably one of the most detailed areas of Chinese law. In many ways, it reflects not only traditional Chinese values but also China's economic and legal development. [13] In 2000, the Ministry of Transport of the People's Republic of China (MOT) commissioned Dalian Maritime University and Shanghai Maritime University to conduct a "scientific research" on revision of the CMC. The research project aimed to study and offer suggestions on the desirable modification of CMC. With Shanghai Maritime University as the leader, the research group has made great achievement and published several papers. The maritime judicial practice, relevant maritime treaties and legislations of developed countries all provide advanced experience for the revision of CMC. According to the research of the scholars concerned, the following issues are the major concerns for $\mathrm{CMC}$ modification:

\subsubsection{Proper Extension of the Application Scope of the CMC}

Chapter 4 of the CMC contains provisions governing the contract of carriage of goods by sea, such as the carrier's responsibilities, shipper's responsibilities and delivery of goods. However, Article 2 of $\mathrm{CMC}$ has excluded the application of Chapter 4 of the CMC to maritime transport of goods between the ports of China. Over the years, domestic seaborne cargo transportation has developed rapidly and a huge inland water transportation network has been built up. The transportation of goods often includes sea-and-river combined transportation. Thus, the CMC shall be revised to extend its scope of application to the inland waters connected with the sea.

\subsubsection{Revision of Chapter 4 of the CMC}

The primary purpose of commercial shipping is to transport goods, whereas disputes are inevitable. The major disputes arise from the shipper and carrier of the goods.[14] The law of carriage of goods by sea is the most important part of the CMC. The Rotterdam Rules is the latest international Convention which has a scope similar to that of Chapter 4 in the CMC. Thus, even if China declines to ratify Rotterdam Rules, the Rules may serve as reference. China's attitude towards ratification of the Rules depends on its effect on the overall economic interests of the country, and is also influenced by the attitude of major shipping and trading countries towards the Rules. [15]

As one of the biggest shipping and trading country in the world, China plays an influential role in shaping the regime of maritime transportation in the world. Although China has some large shipping companies, there are many small and medium-sized international shipping or trading enterprises in China whose competitiveness is not strong in the international shipping market. One of the concerns is the effect of Article 80 of the Rules. Article 80 provides that notwithstanding article 79, between the carrier and the shipper, a volume contract to which this Convention applies may provide for greater or lesser rights, obligations and liabilities than those imposed by this Convention. In effect, it provides an exit to the mandatory application of the Rules. Without doubt the Article has adverse effect on many Chinese shipping or trading enterprises who do not have strong bargaining power. Nevertheless, the Rules are valuable for China to explore and build its Maritime Code. Many well-drafted articles in the Rotterdam Rules could be absorbed and used as reference in the revision of maritime law, such as provisions of maritime performing parties, international multi-modal transport of goods, transport documents and electronic transport records, as well as control rights. [16]

\subsubsection{Creation of Liability Rules for Damages and Pollution at Sea by Vessels}

Referring to the International Convention on Civil Liability for Oil Pollution Damage of 1992, the International Convention on Civil Liability for Oil Pollution Damage of 2001, and Convention on the Liability and Compensation for Damage to Toxic and Harmful Substances in International Maritime Transport of 1996, these Conventions stipulate the responsible party of the sea pollution, doctrine of liability fixation, exemption conditions, scope of compensation, limitation of liability, compulsory liability insurance, compensation fund for the sea pollution by vessels and so on. China needs to catch up with the international standard on oil pollution liabilities.

\subsubsection{Perfection of the Rights and Interests of Crewmen in CMC}

Crewmen are the most crucial factor of production in the international shipping industry. Crewmen have to stay on board for months or years during long voyages, in the course of which they are exposed to special hazards. They often have to deal with perils of the sea themselves frequently at remote areas distant from help onshore, such as the fire brigade readily available on land. [17] Therefore, specific legislations to protect crewmen in domestic law and international law are necessary. Chapter 3 of CMC fails to provide similar protection. It is only stated in Article 34 that "in the absence of specific stipulations in this Code as regards the employment of the crew as well as their labourrelated rights and obligations, the provisions of the relevant 
laws and administrative rules and regulations shall apply." Due to the growing demand for protection of the rights and interests of the crew and the change of their employment patterns, the focus of legislation related to crewmen is shifted from the required competency to the protection of the rights and interests of the crew. The International Labor Organization adopted the Maritime Labor Convention of 2006 on February 23rd, 2006. China is now one of the member states having ratified the Convention. Therefore, provisions relating to employment conditions of crewmen and the protection of their rights and interests shall be added to the third chapter of CMC. It will be discussed further in the next section.

\subsubsection{Revision of Other Chapters of CMC}

Chapter 5 of CMC, Contract of Carriage of Passengers by Sea, shall be amended to adapt to the decline of traditional domestic sea passenger transport and the rapid development of the international passenger transportation. It should set a higher limitation of liabilities for carriers regarding passengers' personal injury on board, because of the increased income and improved living standard. The revision of Chapter 6, Charter Parties, should take into account the rise of ship financing and leasing. Chapter 11, the Limitation of Liability for Maritime Claims, shall be amended to adapt to the demand of higher limitation of liability for maritime claims.

\subsection{Other Maritime Legislation Issues in China}

\subsubsection{Enforcement of Waterway Law of the People's Republic of China}

Waterway is the infrastructure of water carriage. The law relating to waterway is a matter of public welfare. China passed Waterway Law of the People's Republic of China (hereafter referred to as Waterway Law) at the 12th Session of the Standing Committee of the Twelfth National People's Congress on December 28th, 2014. [18] It came into force on March 1st, 2015. The legislation aimed at regulating and enhancing the planning, construction, maintenance, and protection of waterways, as well as ensuring navigability and navigation safety of waterways and promoting the development of water transportation. Waterway Law consists of 48 articles in 7 Chapters: General Provisions, Waterway Planning, Construction of Waterways, Maintenance of Waterways, Protection of Waterways, Legal Liability and Supplementary Provisions. The fundamental purpose of waterway legislation is to ensure that the strategic resources of the channel are fully and effectively utilized. Waterway Law provides legal protection for capital investment of construction and maintenance of waterways. Since waterway requires substantial capital investment at the initial construction stage and continuous capital investment for long-term management and maintenance, Article 4 of the Waterway Law adds the content of the responsibility of the State Council and local people's governments at all levels for waterway management and capital investment, which provides clear legal protection for the investment of waterway construction and maintenance. Waterway Law is conducive to full protection and utilization of waterway strategic resources. Waterway is not only a public welfare infrastructure, but also an important strategic resource.

\subsubsection{China's Ratification of the Maritime Labor Convention of 2006}

Employees at sea has a hard life with poor conditions and great exploitation. For the poorly organized and ill-lookedafter men responsible for the safe arrival of passengers and cargo at their proper destination, the risks and dangers inherent in the work are self-evident. The conditions of employment are mostly contained in the contract of employment. [19] The Maritime Labor Convention of 2006 was adopted at the 94th International Labor Conference of the International Labor Organization on February 23rd, 2006 and entered into force on August 20th, 2013. The Convention provides detailed and clear provisions on protection of crewmen's rights and various obligations for the Member States to comply with, such as the minimum standard for seafarers' work, employment conditions, accommodation, recreational facilities, food and catering services, health protection, and medical care, welfare and social security compliance, enforcement and other five aspects. It is commonly known as the International Seafarers' Bill of Rights.

On August 29th, 2015, the Sixteenth Session of the Standing Committee of the Twelfth National People's Congress considered, approved and formally ratified the Maritime Labor Convention in China. The Convention entered into force one year after the date of submission of the instrument of ratification to the International Labor Office. Compared to the United Kingdom, the UK has incorporated more generous and detailed provisions proposed by the National Maritime Board (NMB), a body representing both sides of the shipping industry, established in 1919. The NMB published Summary of Agreements and provided information on standard rates of salary, conditions of employment and decisions on various matters such as catering, electric lights, death or injury during warlike operations, repatriation in the event of dangerous illness, absence without leave and training allowances, to mention only a few. [20] China has yet to draft and incorporate further detailed provisions on protection of seafarers. In Decision of the Standing Committee of the National People's Congress on Ratifying the Maritime Labour Convention of 2006, China has only supplemented the following Contents: firstly, in compliance with paragraph 10 of Standard A4.5 of the Convention, China states in the Decision that the branches for social insurance protection applicable to China are pension insurance, medical insurance, industrial injury insurance, unemployment insurance and maternity insurance; secondly, it is provided that unless the Chinese government promulgates so, the Convention is not applicable to Hong Kong and Macao Special Administrative Regions of China. 


\subsubsection{Other Regulations and Administrative Rules Promulgated by the MOT in China}

(a) Provisions on the Administration of Domestic Waterways

In order to complement with the implementation of Regulations on the Administration of Domestic Water Transport, [21] the MOT of PRC enacted the Provisions on the Administration of Domestic Water Transport on December 30th, 2013 [22] and Provisions on the Administration of Auxiliary Business for Domestic Water Transport on March 1st, 2014. [23] After the implementation of Provisions on the Administration of Domestic Waterways, the MOT promulgated the Decisions on Amending the Provisions on the Administration of Domestic Waterway Transport on May 12th, 2015, clarifying that the MOT will not issue the license for the waterway transportation to foreign invested enterprises any longer. Later, the Ministry of Transport promulgated Notice of the Ministry of Transport on Effectively Conducting the Work concerning the Delegation of Approval of Domestic Waterway Transport by Foreign-Funded Enterprises to Lower Levels, [24] specifying that "approval of waterway transport in coastal waters, rivers, lakes and other navigable waters in the PRC by wholly foreign-owned enterprises, Chinese-foreign equity joint ventures, and Chinese-foreign contractual joint ventures $\cdots$ shall be delegated to the transport administrative departments of provincial people's governments". The Notice also required smooth decentralization, as well as approval management and supervision work after the decentralization.

(b) Provisions of the PRC on the Conditions for Maritime Administrative Licensing

On May 29th, 2015, the MOT promulgated the Provisions of the PRC on the Conditions for Maritime Administrative Licensing [25] and Provisions of the People's Republic of China on Inland-Water-Related Maritime Administrative Penalties [26]. Both provisions took effect from July 1st, 2015. Compared to the Provisions of the PRC on the Conditions Maritime Administrative Licensing issued in 2006 which has now been repealed, the 2015 Provisions has four main changes. First, part of the administrative licensing items and requirements are added, such as Article 24 which regulates the qualification and registration requirements for workers who are responsible for transporting dangerous chemicals. Second, some of the items and requirements have been removed, such as the permission requirements for excavation, blasting work in port area regulated by Article 8 of Provisions of the PRC Concerning Maritime Administrative Licensing in 2005. Third, the names of the maritime administrative licensing items have been modified. For example, Article 7, "construction permission in the water and above navigable waters" is replaced by "activity permission in the water and above navigable waters". Fourth, part of the requirements for maritime administrative licensing items are modified. For example, Paragraph 5 of Article 8, if the salvage and demolishment of shipwrecks or sunken objects severely hampers safety and cause pollution, these measures are not required to pass environmental impact assessment. [26]

(c) The Documents of Shipping Policy under State Council and the MOT

This document was promulgated on January 5th, 2015 which stated eleven missions. Among them, strengthening legal service for shipping matter is one of the main missions. MOT aims to improve shipping law service system, especially maritime arbitration and maritime claims.

Announcement of the Ministry of Transport on Policies for the Pilot Programs of Maritime Transportation in National Free Trade Zones was promulgated on June 6th, 2015. [27] The Ministry of Transport has put forward seven marine policies that would be implemented in the Free trade Zones (FTZ) - Guangdong, Tianjin, Fujian and Shanghai. First, "with the approval from the transport department of the State Council, foreign investors may establish Chinese-foreign equity or contractual joint ventures without any limitation on the shareholding ratio in the FTZ to engage in international shipping activities to and from Chinese ports; in particular, a wholly foreign-owned enterprise may be established in China (Shanghai) Pilot Free Trade Zone, and a wholly Hong Kongfunded or Macao-funded enterprise may be established in China (Guangdong) Pilot Free Trade Zone...". In other words, foreign investors can establish Chinese-joint ventures in the FTZ and/or start its own enterprise in Shanghai running international shipping business to and from Chinese ports.

Second, "with the approval of the transport department of the State Council, a Chinese-foreign equity or contractual joint venture established in the FTZ may engage in public international shipping agency services, with the foreign shareholding ratio relaxed to $51 \%$; a wholly foreign-owned enterprise established in the FTZ may engage in the loading and unloading of international maritime shipments and international maritime container freight station and container yard services".[27] In essence, the relaxation of foreign shareholding ratio to $51 \%$ would remove the barrier of blocking foreign investors from the right of control in the company.

Third, "with the approval of the transport department of the province where the FTZ is located, a wholly foreignowned enterprise established in the FTZ may engage in international ship management". [27]

Fourth, "for the Chinese-foreign equity or contractual joint venture established in the FTZ, the chairman of board and general manager shall be agreed upon by both parties". [27]

\section{Release of Maritime Model Cases and Their Legal Value}

Model cases are released by the Supreme People's Court from time to time. They are important decisions selected out of many cases heard before the Chinese Courts. Unlike "case law" in common law jurisdictions, model cases do not have binding effect. Rather, they are released to demonstrate the application, reasoning and interpretation of law in actual 
disputes. [28] As Dong Hao observed, the major objectives for these model cases are to illustrate the application of the law and improve legal transparency. [29]

Since these cases are released by the highest Court in China, it is argued that they will influence judge's decisionmaking. However, the degree of influence of the model cases on judicial decision-making is unclear. Unlike the practice in commonwealth jurisdictions, model cases are not cited in the judgment. However, they still serve as important guidance for future trials.

On September 22nd, 2014, the Supreme People's Court released ten maritime model cases at the conference celebrating the 30th anniversary of establishment of maritime court in China.

\subsection{Granville Shipping Company, Chen Zhen, and Chen Chun v. Mitsui O. S. K. Lines, Ltd}

The dispute arose out of a time charter party. The charter party contained a clause "...vessels may not be required to enter any port in the status of embargo or any port where acts of hostility were undergoing [and] may not conduct any voyage that was likely to cause such risks as confiscation, withholding, or punishment by the governor or government." The charterer (Tatung Shipping Co. Ltd, predecessor of Mitsui O. S. K Line Ltd) ordered the ship to enter a port in Japan. The chartered ships were eventually confiscated by Japanese military and sunk. The charterer was also sued for unpaid hires.

The Court ruled in favor of the claimants. The Court did not differentiate the case from an ordinary breach of time charter party claims for the outbreak of war between Japan and China. [30]

\subsection{Maersk (China) Line Co., Ltd. Xiamen Branch, and China Ocean Shipping Agency Xiamen v. Xiamen Yinghai Industrial Development Co., Ltd}

The parties had a dispute over compensation for damages to International Maritime Freight Forwarding and Management Right.

The maritime court has made detailed discussion on the scope of "public carrier" prescribed in Article 289 of Contract Law of the PRC. It is held that container liner shipping does not fall within "public carrier" in Article 289 of Contract Law of the PRC, and thus, does not have compulsory contracting obligations. The case clarified the difference between "common carrier" and "public transport".

\subsection{JP Morgan Chase \& Co v. Seastream Shipping Inc}

This case arose out of a ship mortgage. When the mortgagor failed to repay the loan, the mortgagee decided to arrest the ship and instituted proceedings in China. However, the essence of the case is that the parties have chosen foreign maritime law as the governing law (Bahamas Merchant Shipping Act). As such, the Court has to apply conflict of law rules.

The case illustrates the application of the three-step test "foreign elements - jurisdiction - application of law", for deciding cases where either party in the dispute takes foreign law as the applicable law. This case serves as guidance for future cases which similarly involve the application of foreign law.

\subsection{Zhejiang Textiles Import \& Export Group Co., Ltd. v. Evergreen International Storage \& Transport Corp}

As a rule of thumb, the carrier shall only deliver the goods upon the receiver's presentation of bills of lading. Nevertheless, it is not uncommon that carrier sometimes releases the goods without bill of lading.

In this case, Zhejiang Textiles Import \& Export Group Co., Ltd., through its agency companies, concluded various shipping contracts with the carrier, Evergreen International Storage \& Transport Corp. to deliver the goods to the consignee. Zhejiang Textiles, after receiving the bills of lading, deposited the bills in the bank and arranged the bank to receive money from the consignee. However, the consignee did not pay and collect the bills of lading from the bank. Rather, the consignee collected the goods from the carrier when the carrier wrongfully released the goods.

As expected, the Court allowed Zhejiang Textiles' claim. This case reiterated that a carrier release the goods to the third party who failed to present the bills of lading acts at its peril. One of the controversies in this case stemmed from that Zhejiang Textiles was not named as the shipper on the bills of lading. The Court approved Zhejiang Textiles' qualification as shipper for three reasons. Firstly, Zhejiang Textiles was the actual deliverer of goods to the carrier. Secondly, Zhejiang Textiles received the bills of lading issued by the carrier. Thirdly, Zhejiang Textile fulfilled the responsibility in the sales contract of handing over the bills to the bank.

The Supreme People's Court has also issued judicial interpretation making similar clarification in 2009. [31]

\subsection{Panama Trade Expansion Shipping Company and \\ Hong Kong Weilin Sailing Co., Ltd. v. Zhong Xiaoyuan and Anti-Smuggling Office of the Government of Zhuhai City}

This is a vessel collision compensation claim case. Zhong Xiaoyuan owned the vessel Shanwei 12138. The AntiSmuggling Office of the Government of Zhuhai City requisitioned Shanwei 12138 to engage in anti-smuggling operation. Shanwei 12138 subsequently sank. Zhong Xiaoyuan and Anti-Smuggling Office alleged that the sinking of Shanwei 12138 was caused by the collision with another vessel, Trade Expansion.

The Supreme People's Court rejected Zhong and AntiSmuggling Office's claim. The Court ruled that the claimant failed to produce evidence that satisfies the burden of proof. The Court especially highlighted that no trace of collision damage was found at the bow of Trade Expansion.

The case demonstrates "high probability" test in Chinese law civil dispute in this compensation claim. The standard is 
high and the inconsistency of circumstantial evidence may strike out the claim. In order to establish a claim relying on circumstantial evidence, the various circumstantial evidences put forward must corroborate each other and constitute a complete "evidence chain". [31]

\subsection{Hainan Fenghai Cereals \& Oils Industrial Co., Ltd. v. PICC Property \& Casualty Co., Ltd. Hainan Branch}

It is a dispute based on marine insurance contract. The cargo owner and time charterer of HAGAAG, Hainan Fenghai Cereals \& Oils Industrial Co., Ltd., obtained insurance from the insurer Hainan Branch of PICC Property $\&$ Casualty Co., Ltd. The insurance contract contained an allrisk clause, saying, "[the insurer] was liable for all or partial damages to the insured goods due to any external cause in transit." The contract also provided 5 exclusion clauses.

The case turned unusual when the shipowner and time charterer had a dispute over the payable hire in November 1995. The shipowner decided to suspend service and ordered the ship to set sail to somewhere unknown to the time charterer. Eventually, in April 1996, the ship was captured by China Coast Guard for smuggling cargo to Shanwei. It was found that part of the goods loaded on board had been stolen while the remaining goods were confiscated by the Chinese authorities because of smuggling. Hainan Fenghai sought to claim for the loss from insurer and was successful.

This is an important marine insurance decision as it finally provides clarification on the scope of liability of all-risk insurance clause in marine cargo insurance. The maritime court clarified that, unless otherwise stated, firstly, an all-risk insurance clause provides "unlisted insurance coverage", and the risk listed in the insurance contract is non-exhaustive. Secondly, the cause of the loss has to be external cause. Thirdly, the external cause took place during voyage.

\subsection{He Yuantang, Xu Jianben, and He Yuanjiu v. Guangxi HepuXichangYongxin Sugar Co., Ltd}

He Yuantang, Xu Jianben, and He Yuanjiu operated a farm in Hepu, China. Due to Guangxi HepuXichangYongxin Sugar Co., Ltd.'s illegal sewage discharge, $\mathrm{He}$ and $\mathrm{Xu}$ suffered great loss as a result of the death of the clams. Thus, they launched a claim against the defendant for compensation.

It was not difficult for the court to determine why claimants lost clams.. However, since the claimants did not have the relevant aquaculture certificate or water use license, the Court only allowed the claimants' partial claim for actual loss of the clams and rejected the claim for loss of profit. The claimants were held partially liable for the loss because of their participation in illegal clam breeding activities.

\subsection{Qian'an No. 1 Paper Mill and Other Eight Enterprises v. Sun Youli and Other 17 Persons}

The claimants of this case, Sun Youli and other 17 persons, operated seafood farms. The defendants, Qian'an No. 1 Paper Mill and other eight enterprises were manufacturing companies. It was alleged that the sewage discharge of the defendants contaminated their seafood farms. The defendants argued in defence that their sewage discharge had complied with the relevant environmental standard. Finally, the Court found the defendants liable but reduced the compensation award taking into account the defendant's compliance with the environmental standard.

Although China's environmental pollution has caused infringement and environmental protection laws have not yet been codified, the maritime court held that in a case of landbased contamination, even if an enterprise discharged sewage adhering to the prescribed standard, the enterprise would still assume the liability to compensate for environmental pollution damages.

\subsection{China Shipping Development Co., Ltd. Freighter Company's Application for the Establishment of the Fund for Limitation of Liability for Maritime Claims}

On May 26th, 2008, the vessel, "Ning'An 11" of the applicant, China Shipping Development Co., Ltd. Freighter Company while trying to berth in Shanghai Waigaoqiao port, collided with the ship unloaders and caused damage to the port. Then, the applicant sought to establish a fund for limitation of liability for maritime claims other than that for loss of file or personal injury according to Article 210 of Maritime Law of the People's Republic of China and Article 4 of Provisions Concerning the Limitation of Liability for Maritime Claims for Ships With a Gross Tonnage Not Exceeding 300 Tons and Those Engaging in Coastal Transport Services As Well As Those for Other Coastal Operations. [32]

In order to determine the application, the Court explained that there were three elements for consideration of the application to establish a limitation of liability fund whether the applicant fulfills the legal requirement for establishing the fund, [33] the nature of claims involved in the accident, and the amount of the fund the applicant seeks to establish.

For the first criterion, Article 210 (5) provides that "the limitation of liability for ships with a gross tonnage not exceeding 300 tons and those engaging in transport services between the ports of the People's Republic of China as well as those for other coastal works shall be worked out by the competent authorities of transport and communications under the State Council and implemented after its being submitted to and approved by the State Council." The Court made an important clarification to determine whether the ship was "engaging in transport services between the ports of the People's Republic of China", and the Court considered the actual voyage that the ship was taking which has caused the damage. The ship's capability to engage in international voyage is irrelevant. As "Ning'An 11" was travelling from Qinhuangdao to Shanghai Waigaoqiao port at the relevant time, the Court was satisfied that "Ning'An 11" had fulfilled the above criterion. The Court also held that the applicant met the remaining criteria and allowed the application.

Overall, this case provides the procedural overview of the 
Court's consideration on an application for establishment of the fund for limitation of liability for maritime claims.

\subsection{Application of First Investment Corp. of the Marshall Islands for Recognition and Enforcement of Arbitration Award of an Ad Hoc Arbitration Tribunal in London}

The Court in this case was faced with the application from First Investment Corp. for recognition and enforcement of an arbitration award. The respondents, Fujian Mawei Shipbuilding Co., Ltd. and Fujian Shipbuilding Industry Group Company Limited and First Investment Corp. entered into a contract, stipulating that "the respondents irrevocably agreed to enter into an Option Shipbuilding Contract with FIC or the designated persons thereof for a maximum of eight vessels". The parties have agreed to incorporate an arbitration clause selecting London as the forum for arbitration and Arbitration Act 1996 and London Maritime Arbitrators Association Terms as the governing laws.

As the respondents acted in breach for failure to sign the shipbuilding contract within the time limit as agreed in the Option Shipbuilding Contract, the applicant initiated arbitration proceedings in London. The arbitrators ruled in favour of First Investment Corp.

Thus First Investment Corp sought to enforce the arbitration award in China. However, the enforcement and recognition of the arbitration award was subject to dispute because the arbitration award was made by two arbitrators only, in the absence of Wang Shengchang, one of the three arbitrators. This is because after two arbitration hearings, Wang Shengchang was arrested by the Chinese authorities and could no longer participate in the arbitration proceedings.

Since China is a signatory to the Convention on the Recognition and Enforcement of Foreign Arbitration Awards 1958, the Court reviewed the application in light of the Convention. The maritime court refused to recognize and enforce the arbitration award, referring to Article V 1 (d) of the Convention. [34] The Court considered that the power of the majority of arbitrators to make decision under paragraph 8 (e) of the LMAA Terms 2006 [35] can only be exercised where all arbitrators sitting in the arbitration tribunal and participating in the whole arbitration proceedings.

\section{Reform of the Chinese Maritime Court's Jurisdiction}

\subsection{The New Criminal Jurisdiction of the Maritime Court}

The Chinese Maritime Courts has just launched the pilot scheme on criminal trials. The legislations of maritime crimes, the burden and standard of proof in criminal case and the guidelines for sentencing are all new to the Maritime Court Judges. Also, many issues have yet to be further revised and settled, such as the jurisdiction and scope of the Maritime Court on trying criminal cases, the process of transferring cases to and from Maritime Courts, and the personnel allocation system.

Common maritime crimes include piracy, crime related to marine traffic accidents, marine environmental pollution and marine living resource crime. Further clarification of maritime criminal law as a category of criminal law has yet to be revealed in the future. It is expected that the Court will also provide answer to questions such as the relationship between maritime law as department law and the Criminal Code when applying Chinese Criminal Code to maritime cases.

On July 6th, 2017, Ningbo Maritime Court held a public court hearing over the case of "Catalina". Allan Mendoza Tablate, the Second Officer of the Maltese bulk cargo ship Catalina"was charged with traffic offence which had caused 14 deaths. [36] It was the first time that a maritime court had heard a criminal case.

This first criminal trial in Ningbo Maritime Court marks the new page of maritime judicial reform - implementing "three in one" mode of trial in the Maritime Courts. [37] It stresses that maritime order should be maintained by Maritime Courts in its judicial role in governing illegal activities at sea. In fact, it is not new to the shipping circle for granting criminal jurisdiction to maritime court. In the 14th century, the Admiralty Court of England also assumed civil and criminal jurisdiction. Admiralty jurisdiction began in the Court of the Lord High Admiral, whose function was to deal with crimes that were committed on the high seas which were not subject to the jurisdiction of the ordinary court. Today, the admiralty jurisdiction is vested in the High Court, as part of the Queen's Bench Division, [38] which was passed in light of the two Brussels Conventions of 1952 on the Arrest of Seagoing Ships and Civil Jurisdiction in Collisions. [39]

The conferment of criminal jurisdiction to Maritime Court established the role of criminal law in maintenance of maritime order. It was also an important decision since new elements of the criminal justice reform were also demonstrated in the trial of the case. [40] The Judge has followed the criminal justice reform objective to adjudicate with leniency and rigidity, balancing the various factors for sentencing.

\subsection{Publication of White Paper on Trials in Maritime Court at Regular Intervals}

Another important measure facilitating the development of admiralty jurisdiction in China is the regular publication of Maritime Trial White Paper. White Papers are published by the Supreme People's Court and various maritime courts. Shanghai Maritime Court, Guangzhou Maritime Court, Xiamen Maritime Court, Beihai Maritime Court, Qingdao Maritime Court and Ningbo Maritime Court have published white papers by the end of 2017.

White Paper summarizes and highlights important decisions made by the Maritime Courts. White paper also reviews the maritime trials and the work of the Maritime Court. It may contain important information for trial in the future. For instance, the China's Maritime Adjudication (1984-2014) discusses measures to improve the management of the Maritime Court, important cases decided, suggestions 
to improve the provision of maritime legal service, suggestions to improve the quality of maritime trials, procedural rules of judicial sale of arrested ships and the law and practice regarding arrest of ships. [41]

\subsection{The Release of Guiding Maritime Cases}

On November 26th, 2010, the Supreme People's Court issued Provisions of the Supreme People's Court on Case Guidance and on May 13th, 2015, Detailed Rules for the Interpretation of the Provisions of the Supreme People's Court on Case Guidance. The two legislations have injected the new element - "guiding case" into the Chinese legal system.

In the past, judicial decision making in China comprises of facts finding and legislation applying. To apply the legislations, the Court is assisted by "Judicial Interpretation" [42]. Judicial Interpretations are formal documents which bears full legal force. [42] They are released by the Supreme People's Court to provide supplementary elaboration of the statutes. Now, Chinese Judges are also required to use the guiding cases "as reference" when trying similar cases. [42]

In contrast to common law legal system where every case tried could become part of the case law, the Supreme People's Court selects and publishes limited number of guiding cases. Guiding cases are neither legally binding nor creating legal rules. Guiding cases cannot be cited as legal authority or become the basis of a decision. However, given the likeliness of a lower court's decision being overturned by a higher court decision upon appeal if the Judge in the lower court neglects or departs from the decision held in a guiding case with similar facts, Judges could often follow the reasoning and rationale of the guiding cases. Therefore, the guiding cases are highly persuasive. During trial, legal representatives of the parties could refer to guiding cases to persuade the Judge.

There are two important guiding cases that are going to be discussed.

On July 5th, 2014, the Supreme People's Court in China issued the Notice of the Supreme People's Court on Issuing the Seventh Group of Guiding Cases. In Guiding Case No. 31, Jiangsu Weilun Shipping Co., Ltd. v. Miranda Rose Company, the parties had a dispute over compensation for damages arising out of the collision between two vessels. The defendant's vessel, Miranda Rose intended to overtake the claimant's vessel, Weilun06. The parties have mutually agreed to let Miranda Rose overtake Weilun 06 in a way contrary to the rules set forth in the International Regulations for Preventing Collisions at Sea 1972. MirandaRose failed to observe their agreement and finally the two vessels collided. The Court held that the parties' liabilities shall be decided "according to the said Regulations and on the basis of comprehensive analysis on reasons for forming such closequarters situation, faults of both vessels involved, and appropriateness of disposal measures". Since both parties had violated the said Regulations, they were equally accountable for the accident. The agreement between the parties and the defendant's subsequent breach of the agreement are irrelevant for determining the liabilities of each party.

On April 23rd, 2015, the Supreme People's Court issued
Notice of the Supreme People's Court on Issuing the Tenth Group of Guiding Cases. Guiding Case No.51 is Hainan Fenghai Cereals \& Oils Industrial Co., Ltd. v. Hainan Branch of PICC Property \& Casualty Co., Ltd. The dispute arose out of a marine cargo insurance contract. Hainan Fenghai entered into an insurance contract with the insurer, Hainan Branch of PICC. The insurance contract contained an all- risks clause.

The insured lodged a claim because the cargo had been confiscated as contraband goods by the law enforcement agency of China due to the shipmaster's illegal appropriation and attempt to smuggle the goods to Shanwei, China. The court ruled that "all risks" in a marine cargo insurance contract covered all or partial losses for external causes in transit of the insured cargoes. Where, in the absence of intention or negligence on the part of the insured, damage to the insured cargo was caused under circumstances other than those listed in the exclusion clauses of the relevant insurance contract, it could be determined that the insured cargo was damaged for "external causes," and the insurer should bear all losses for such external causes in transit. [43] In short, the case clarifies that in absence of an exclusion clause in the insurance contract excluding the specific cause of the loss, an all-risks clause covers specified and unspecified risks. So far as the loss is caused by external factors during transit, the insured could claim for the loss under the insurance policy.

\section{Conclusion}

China is and will continue to be one of the major shipping countries. China's maritime law is the fusion of Western maritime practices and principles and Chinese legal system characteristics. It is foreseeable that China will continue to develop its maritime law at its own pace in light of the development of the shipping industry and international conventions. The influence of Western maritime practice has been seen in many examples. The Chinese legal tradition has been preserved in the development of Chinese maritime law. The theory and practice of China's maritime law is expected to undergo more reforms and refinements in the coming future. At present, China is confronted with many challenges on its track to reform the $\mathrm{CMC}$ and has come to a tough stage. Further discussions are necessary for perfecting the maritime law jurisdiction. The impact of the rise of arbitration as an alternative dispute resolution, the jurisprudential issue of maritime law's relationship with civil law and criminal law, the need for legal protection of the crew's rights and measures for enhancing protection against ocean pollution are all concerns to China. Nevertheless, we're happy to see that the maritime law in China is heading to a better state.

\section{Fund Project}

This article is a periodical result of the Key Project of National Social Science Fund of China, "Research on the security and legal guarantee of the sea passage under the Civil-Military Integration strategy" (Project approval number: 18ZDA155). 


\section{References}

[1] See Lei CHEN, "The Historical Development of the Civil Law Tradition in China: A Private Law Perspective," (2010) 78 The Legal History Review159.

[2] Lihong ZHANG, "The Latest Developments in the Codification of Chinese Civil Law" (2008) 83 Tulane Law Review 999, 1007.

[3] Shiyuan HAN, "Civil Law Codification in China: Its Characteristics, Social Functions and Future" in Wang WenYeu, Codification in East Asia: Selected Papers from 2nd IACL Thematic Conference (2014 Springer)

[4] See Maritime Law of the People's Republic of China.

[5] Robert Grime, Shipping Law (2ndedn, Sweet \& Maxwell 1978) 2.

[6] According to UNCITRAL, up to 22nd March 2018, 25 countries have signed the United Nations Convention on Contracts for the International Carriage of Goods Wholly or Partly by Sea (Rotterdam Rules). Among the signatories, Cameroon, Congo, Spain and Togo have ratified the Rules. UNCITRAL, "Status - United Nations Convention on Contracts for the International Carriage of Goods Wholly or Partly by Sea" (New York 2008) $<$ http://www.uncitral.org/uncitral/en/uncitral_texts/transport_g oods/rotterdam_status.html $>$ accessed 22nd March 2018.

[7] See Maritime Law of the People's Republic of China, supra, art. 257.

[8] YU Guo, Haishangfa de Jingshen, Peking University Press 2005, 83 .

[9] Provisions of the Supreme People's Court on the Judicial Interpretation Work, art. 5.

[10] Deyi MA, "The Richness and System of Maritime Law as Supplementary Civil Law", 8 Social Science Front 202, 202-203.

[11] Ibid 206. Also, as Robert Hillman speculates, "Contract law includes a rich combination of normative approaches and theories of obligation. It is divided by special rules for distinct kinds of contracts and is subject to many exceptions and counter-principles. Despite its many dimensions, contract law is a credible, if not flawless, reflection of the values of the surrounding society. A highly abstract unitary theory illuminates contract law, but it cannot explain the entire sphere." Robert A. Hillman, The Richness of Contract Law: An Analysis and Critique of Contemporary Theories of Contract Law (Springer 2012), 6 .

[12] Zhengliang HU and Siqi SUN, "The Basic Issues and Main Proposals for the Revision of the Chinese Maritime Code" (2017) 4 Chinese Revision of International Law 53, 53-54.

[13] Eckart J. Broedermann, "China and Admiralty-An Introduction to Chinese Maritime Law and U. S-Chinese Shipping Relations" (1985) 16, Journal of Maritime Law \& Commerce 65, 65-68.

[14] See Leon E. Trakman The Law Merchant: The Evolution of Commercial Law. Fred B. Rothman\& Co. Littleton 1983, 27-36.

[15] Zhengliang HU, Shicheng YU \&BingguiJiaRotterdam Rules: Consequences and Countermeasures. Peking University Press 2014, 445-449.
[16] In an attempt to prevent further fragmentation, a new international initiative was launched. The Convention, "The Rotterdam Rules", has been drafted and opened for signature from 23 September 2009. See John F. Wilson, Carriage of Goods by Sea (7thedn Longman 2010), 230.

[17] N. J. J. Gaskell, C. Debattista and R. J. Swatton, Chorley \& Giles, Shipping Law, Pitman Publishing 1987, 109-110.

[18] Paragraph 3 of Article 28 of Waterway Law has been amended according to "Decision of the Standing Committee of the National People's Congress on Amending Six Laws including the Energy Conservation Law of the People's Republic of China (including the Water Law of the People's Republic of China, the Law of the People's Republic of China on Flood Control, the Law of the People's Republic of China on the Prevention and Control of Occupational Diseases, the Waterway Law of the People's Republic of China and the Law of the People's Republic of China on Environmental Impact Assessment" on 2nd July 2016. The Decision provides that "Paragraph 3 of Article 28 is amended to read: "The construction entity shall not commence construction if the impact of waterway navigation conditions is not assessed or if the examination department deems upon examination that the construction project fails to comply with the provisions of this Law. If a government investment project fails to undergo waterway navigation condition impact assessment or the examination department deems upon examination that the construction project fails to comply with the provisions of this Law, the department responsible for the approval of the construction project shall not grant approval."

[19] Robert Grime, supra, 41-42.

[20] N. J. J. Gaskell, C. Debattista and R. J. Swatton, supra, 115.

[21] Regulation on the Administration of Domestic Water Transport.

[22] Provisions on the Administration of Domestic Water Transport.

[23] Provisions on the Administration of the Ancillary Business for Domestic Water Transport.

[24] Notice of the Ministry of Transport on Effectively Conducting the Work concerning the Delegation of Approval of Domestic Waterway Transport by Foreign-Funded Enterprises to Lower Levels.

[25] See Provisions of the People's Republic of China on the Conditions for Maritime Administrative Licensing Amendment, 2016.

[26] See Provisions of the People's Republic of China on InlandWater-Related Maritime Administrative Penalties.

[27] See Announcement of the Ministry of Transport on Policies for the Pilot Programs of Maritime Transportation in National Free Trade Zones.

[28] As scholars have observed, there are four types of cases being released. Type 1 cases restate the law which the facts in the cases fall neatly under the law. Type 2 cases provide literal interpretation of the law. Type 3 cases remedy the mischief of law. Type 4 cases demonstrate the application and interpretation of law when the law is ambiguous which a simple literal interpretation fails to resolve the uncertainty in the law. http://www.iolaw.org.cn/showNews.asp?id=31664> accessed 22 March 2018. 
[29] Ibid, DONG Hao, et al., 99.

[30] See Supreme People's Court, Ten Model Cases in Maritime Trial, 3rd September, 2014.

[31] See Provisions of the Supreme People's Court on Several Issues concerning the Application of Law during the Trial of Cases about Delivery of Goods without an Original Bill of Lading, Article 11, "The holder of an original bill of lading may require a carrier delivering goods without the original bill of lading and the person taking delivery of goods without the original bill of lading to bear the joint and several liability."

[32] See Provisions Concerning the Limitation of Liability for Maritime Claims for Ships With a Gross Tonnage Not Exceeding 300 Tons and Those Engaging in Coastal Transport Services As Well As Those for Other Coastal Operations.

[33] Ibid, Article 2, "These Provisions shall apply to the ships with a gross tonnage exceeding 20 tons and not exceeding 300 tons, and those with a gross tonnage exceeding 300 tons engaging in transport services between the ports of the People's Republic of China as well as those for other coastal operations."

[34] "Recognition and enforcement of the award may be refused, at the request of the party against whom it is invoked, only if that party furnishes to the competent authority where the recognition and enforcement is sought, proof that: (d) The composition of the arbitral authority or the arbitral procedure was not in accordance with the agreement of the parties, or, failing such agreement, was not in accordance with the law of the country where the arbitration took place;"

[35] "If the tribunal is to consist of three arbitrators: (e) after the appointment of the third arbitrator decisions, orders or awards shall be made by all or a majority of the arbitrators."

[36] See "The Judgment of the 2nd Mate of M/V Catalina, Allan Mendoza Tablate"

$<$ http://ccmt.court.gov.cn/haishi/unintercept/newsdetials.do?ne wsId=316>accessed 14 September 2017 .
[37] "Three in one" mode of trial of is the conferment of criminal, civil and administrative jurisdiction to the Maritime Court. Since Maritime Court Judges have expertise in the "maritime elements" of the maritime criminal cases, instead of having criminal trials take place in general courts, the reform improves the efficacy and efficiency of maritime criminal trials. See also, (2017) "On Sea Law" (<http://www.faxueyanjiu.com/ch/reader/create_pdf.aspx?file no $=20170605 \&$ flag $=1 \&$ journal $\_$id $=$fxyj\&year $i d=2017>$ accessed on 22nd March 2018

[38] Senior Courts Act 1981 Article 6 (2).

[39] Thomas J. Schoenbaum and A. M. N. Yiannpoulos Admiralty and Maritime Law, The Michie Company Law Publishers 2004, 3 .

[40] In 2010 the Supreme People's Court issued Notice of the Supreme People's Court on Issuing the Some Advice on Implementing the Criminal Policy of Combining Leniency with Rigidity. The Notice aimed to provide guidelines to courts at all levels for criminal adjudication.

[41] Supreme People's Court, "China's Maritime Adjudication (1984-2014)" (26 October 2016) $<$ http://encemt.court.gov.cn/chinamaritimetrial/201610/26/c_59481.htm> accessed 14April 2018.

[42] See Provisions of the Supreme People's Court on the Judicial Interpretation Work.

[43] The first cover of a marine policy is perils of the sea. Rule 7 of the Rules for the Construction of the Policy states that the term "perils of the seas" refers only to "fortuitous accidents or casualties of the seas." It does not refer to the "ordinary action of the wind and waves." See Robert Grime, supra, 244. 